\title{
Human Resource Reforms in Public Administration: The Importance of the Reward System
}

Christopher, DE FREITAS BRADLEY, M.D. PhD Student, 'Valahia' University of Targoviste chrisbradleymd@yahoo.com

\begin{abstract}
Human resource management encompasses administrating and managing human resources or otherwise known as employees. The HR or Human Resources department of any company, whether it be public or private, deals with the day to aspects pertaining to employees, from the recruitment process to probably the most important aspect for any employee; remuneration and benefits. The importance of finding a perfect equilibrium between monetary and non-monetary incentives is crucial in obtaining an efficient work environment, as well as increasing productivity and employee motivation. Having an administrative background or knowledge is essential for any HR manager, in order to detect and implement the most beneficial reward system for both implicated parties.

This paper aims to examine human resource reforms in public administration, primarily in reference to the remunerations of civil servants and employees by giving examples of the importance of salary within the structure of human resource management, looking at new laws involving the increase of salaries within the near future, concluding with suggestions on improving the reward system implemented by human resource managers in Romania's system of public administration.
\end{abstract}

Keywords: Human resource management; employee reward system; salary; payroll legislation JEL Classification: H7, J3, J5.

\section{Introduction}

In order to fully comprehend what reforms are necessary in human resource management and public administration laws, one must first understand what HRM (Human Resource Management) is and what it deals with, so as to maximize the potential of employees and civil servants alike. Human resource management is exactly what it sounds like, the management of human resources and is predominantly involved in the administration of individuals within an institution or organization. The HR department of any organization is involved in 
various tasks, overseeing all facets pertaining to the employees of that organization, from the recruitment, training and investing in the development of potential employees to probably the most important aspect for any employee, remuneration and benefit systems.

During an interview with a potential candidate for a job opening, there are many criteria a recruitment officer looks for in the selection process; education, previous experience, future goals and objectives, and what expectations the candidate has from the organization. This is where the expectations for salary usually comes into play and also where the importance for the HR department to entice and eventually convince the potential candidate with an attractive salary package and benefits, consequently warding off competitors. These actions lead to an increase in employee expectations, which in turn also gives rise to the expectations of organizations, ultimately resulting in new reforms to comply with the growing demands. Although salary is an important factor in helping an individual to make his decision, there are other factors which will also be taken into consideration, the overall goal of a functioning human resource management system is to find a balance between financial and non-financial rewards which should result in maximizing employee motivation and output.

\section{Human Resource Management and the Reward System}

In order to further clarify the modern perspective on what is more commonly referred to as "human resources", let us also address the fundamental question: "Which are the most important resources a human possess that allows them to carry out their professional activity as a human resource?" The answer becomes increasingly more difficult if we were to try and list all of them for each department found in an organization, whether it be public or private. It is easier to give a simpler and more generic response, specifically, competence and performance. These are the two general characteristics relevant to the human resource existing within or necessary to an organization.

The interest in a rewarding system and policy implemented in public administration institutions is based on the fact that the system and the policies are able to grab the employees attention and increase their interest, not only pertaining to achievements in individual performances but particularly for their contribution in increasing global productivity these enterprises in the near future. 
On the other hand, the main challenge faced by a reward system for civil servants is the need to implement the most rational use of the organization's resources and at the same time to ensure the balance between human aspirations and the competitiveness requirements imposed by the system. According to specialists, the reward system determines the size and types of values (material and non-material) that employees receive in exchange for their activities in an institution.

Normally, any reward system for employees in the public system must be based on a set of principles, i.e. include both a financial component and a non-financial reward component. Within the reward system, one of the most important elements is the salary income system. In Romania, the civil servant's salary system is regulated by law, and is composed of the following elements: the basic salary, salary bonuses, bonuses and incentives for financial merit.

In this respect, rewarding civil servants can be defined as "the sum of the values (material and non-material) received by a public servant from the institution in exchange for their efforts, which contribute directly in achieving the objectives of the organization". From a managerial perspective, the reward system represents the collection of material and non-material, financial and nonfinancial revenues, facilities or benefits attributed to the individual according to the level of competence in which the activity was carried out. From the point of view of the functions the system performs, we can say that any reward system follows the following principles:

- To offer the motivational foundation for employees in public institutions - who will always be conscious and motivated by the fact that as long as they contribute to the achievement of the institution's objectives, they will be reward for their efforts (material and nonmaterial) values;

- $\quad$ To provide the financial foundation for attracting, retaining, motivating and satisfying the employees. As a classification, the reward of a civil servant is divided into two main categories, direct reward and indirect reward. In turn, both direct rewards and indirect rewards can take different forms.

Therefore, in light of the facts mentioned above, a system of rewarding civil servants should consider the following characteristics:

- It has to be balanced, in the sense that it should include both material and non-material rewarding elements;

- It should not be used as a tool of coercion and punishment against employees of the institution; 
- Ensuring a degree of fairness is important, rewards must be granted according to the individual contribution of the employees in achieving the objectives of the institution;

- The reward system should not encourage competition between employees. Especially within public institutions, competitive behavior should be limited, in order to do so the logical approach would be to implement a collective rewarding system, rather than an individual one.

- The reward system should include rewarding elements that encourage employee responsibility, but at the same time motivate them to take risks and involve themselves in more difficult collaborations with greater benefits.

\section{Employee salary system}

As a general definition, salary currently represents "a fixed sum of money given to an employee by an employer on a regular (usually monthly) basis for their services". Some human resources and management specialists believe that salary represents a reward for each employee in exchange for their contribution to the success of the organization.

A salary system has two major consequences on organizations and their employees. Firstly, salary is often one of the most important elements related to the costs and expenses generated by public institutions, the effort to minimize the level of expenditure is an essential requirement in maintaining and even increasing efficiency, competitiveness and most the image of the institution on the market which leads to an increase in the workforce capacity. Secondly, salaries are typically the main means of subsistence for employees in the public administration sector (both local and central government) and their families, which will lead them to try to maximize their salary, not only to get a minimum subsistence, but to get as much profit as possible.

There are also other motivating factors besides salary, which can motivate employees and improve workforce productivity. Some motivating factors are as follows; attractive package of benefits; attractiveness of work; professional development; knowledge and experience; flexibility; creativity; stability/safety (Savulescu, 2017).

There are also a number of demotivating factors which can attribute to a decrease output and result in a hostile work environment, resulting in unpleasant circumstances for the entire organization. Certain demotivating 
factors can be; lack of recognition for efforts; urgent tasks; non-involvement; incompetence; income; impact on personal life; routine; inequality(Savulescu, 2017).

Taking all these factors into account, it is apparent why there is a need to find an equilibrium between executing attributed tasks with competency and the reward system put in place by the institution.

\section{Payroll Legislation in Romania}

According to Law no. 330/2010 on the unitary remuneration of the staff paid from public funds, the salary system for civil servants is defined as the system that regulates the remuneration of the personnel in the budgetary sector in relation to the work completed, the quantity, quality, social importance of labor, the conditions in which it is carried out and the results obtained on the basis of certain principles (Article 11 of Law No 330/2010).

In a market economy, any private-sector enterprise enjoys the freedom to consider its own pay system while still complying with regulations or payroll legislation. In the case of public institutions, there is still some tendency for centralized guidance from the central public authorities on the development of wage systems either on the whole system or on some of its components. It should, however, be noted that regardless of the form in which the organization operates (public or private domain), regardless of the form of ownership and form of capital, it is obliged to respect a certain minimum gross salary in the economy and established by law. When devising a pay successful pay system the following principles should be taken under consideration;

Equity of pay - equal work, equal pay. This principle assumes that two or more people who perform the same work in terms of quantity and quality must receive the same salary without any discrimination of age, gender, religion, political beliefs or ethnic origin;

Differentiation by labor - This principle stipulates that wages are expressed in total hours of work per month or per hour. By means of time rules, where appropriate, salary can be calculated for different operations or projects;

Variation in employees' professional qualifications - A principle necessary in stimulating the staff to continuously raise their level of training, both for their own benefit and for the benefit of the institution, by increasing the productivity of their work. The higher the qualification, the higher the contribution, which justifies a higher pay. The principle is based on the fact that skilled work produces more products, achieves more tasks and offers services of higher value 
(quantitative and qualitative) in a shorter timeframe than an unqualified workforce. An employee from a qualified public institution must be able to perform high quality and complex work inaccessible to the unskilled worker. When differentiating salaries, the time and costs required to obtain the qualification must also be taken into account;

Differentiated according to working conditions - this principle stipulates that the salary should also take into account the conditions under which work is done, by granting wages higher to those who work in heavier conditions. As a result, the wages of a hard-working employees must exceed the wages of the normal or light worker;

Salary Confidentiality - this principle should be the basis of all payroll systems irrespective of the type and size of the organization. In practice, it means prohibiting other people from communicating salaries to employees of that company. The collective labor agreements of some companies stipulated that the persons with duties of service who have access to the individual salaries of the staff will be sanctioned administratively, with the termination of the employment contract if they communicate individual wages or total earnings made by company employees to other employees of the company or other individuals. It is also important, when setting wages for employees, to take into account the level of salaries and labor market additions made by competitors.

Generally, in terms of building elements, the salary income of a civil servant consists of two main components: a fixed part of salary (basic salary + bonuses and basic salary allowances) and a variable component composed of bonuses and compensations (according to the law). These compensations are offered as rights to civil servants in exchange for working overtime, vacationing on Romanian territory, legal holidays, etc. Along with these rights, civil servants also have the right to paid or medical leave, go on strike, request professional training, medical assistance and prostheses, pension and other social security rights. (C.Savulescu)

Base salary is the amount of fixed money a civil servant receives for the time worked, i.e. the number of hours worked in a day, month or year. Obviously, this amount of money received by the civil servant varies depending on the work done, the level of difficulty of the tasks performed and completed education. Theoretically, according to the provisions of Law no. 330/2010 regarding the unitary salary of the staff employed by public institutions, the base salary received by the civil servant depends more on the time worked than on the performance of his work. Practically, when determining the basic salary, more emphasis is placed on the level of graduate education, the length of service 
of the employee, the difficulty of the tasks in the job description and less of how effective and efficient the employee is in completing the tasks. In this respect, according to Law no. 330/2010 on the unitary remuneration of staff paid out of public funds, basic salaries shall be differentiated by degrees, higher education, short-term studies and vocational grades in the case of medium-sized studies, so as to ensure the possibility of differentiating individual basic salaries In relation to the level of professional training of each person and his experience at work (Article 13, paragraph 2). According to the aforementioned law, within each grade or professional level, the basic salary differentiation is based on 5 promotions corresponding to the 5 seniority installments, except for the public functions, where only 3 professional grades are used (Article 13 paragraph 2 of Law No. 330/2010).

Salaries and wage allowances generally represent a certain amount of money, mainly determined as a percentage of the basic salary, granted to civil servants carrying out activities of a particular nature or activities under difficult working conditions. In other words, bonuses and allowances represent a part of the earnings, in relation to the conditions in which civil servants work. For example, in the category of special activities we can find the activity of employees of the police, secret services, security services and dignitaries, some of the employees of the justice department (prosecutor's office, anti-corruption offices and employees from certain control and supervision agencies). The category of activities carried out under heavy conditions encompasses the activity of the firefighters, activities carried out at night or in shifts by the employees of the hospitals or other public agencies, activities performed in open air regardless of the atmospheric conditions, activities that involves a sustained physical effort. According to Law no. 330/2010, the amount of bonuses and indemnities must not exceed $30 \%$ of the value of the basic salary (Article 13 paragraph 4 of Law No. 330/2010).

On the one hand, wages and salaries, as a value, are calculated as a percentage of the basic salary. For example, census allowance for diplomatic staff represents $15 \%$ of the basic salary; Night rate $25 \%$ of the base salary value. On the other hand, bonuses and salary allowances do not concern the performance of civil servants, but are granted solely on the basis of the type and nature of their activity. Incentives and prizes can be seen as a variable element in wage income, and have as purpose the rewarding value of civil servants with high performance in their work. In other words, incentives and prizes are the amount of money received by the civil servant, monthly or annually, within the limits of the approved incentive fund, for rewarding his exceptional merits in his 
work. This category of earnings, by itself being granted only on performance criteria (or should be granted only on performance criteria) is variable and timelimited, meaning that these amounts are not granted for an unlimited period as In the case of basic salary and bonuses (salary benefits).

According to the mode of construction of the salary system, the performance in the activity performed by the civil servant is no longer a major factor in influencing the salary received by him. In practice, although the public sector is often criticized for lack of efficiency, effectiveness, or lack of high productivity, by law, we only continue to encourage the lack of performance or encourage the productivity growth of employees in this sector. The civil servants' evaluation process begins to lose quite a lot of value, that the salary received annually by a civil servant is little dependent on the grade received in the annual evaluation of his performance. The principle of equitable remuneration for performance is violated, in terms of prizes and incentives. Basically, an employee with high performance (high productivity) will receive the same amount of money as a colleague of theirs who besides the fact that they showed up to work all year, they didn't manage to record any notable performances and yet they both still manage to receive a smaller amount than his direct boss or the directors of the institution (although his productivity is higher than that of the bosses).

\section{New reforms for 2017}

Contract civil servants in the public administration will have the highest average wage growth in 2017 if the draft law on unit wage elaborated by the Ministry of Labor is adopted in the form presented in May 2017 at the Tripartite National Council for Social Dialogue.

There will be an approximate $65 \%$ increase of the average base salary provided for contract staff in the public administration in 2017 compared to the level in May 2016. Thus, the average basic salary of contract staff will increase from 1,304 RON in May 2016 to 2,151 RON in 2017, if the draft law is adopted in the form presented by the Ministry of Labor.

An increase of $58.4 \%$ was seen in the average base salary for Defense and Public Order staff in 2017 compared to the level of the same indicator in May 2016. Thus, the average core salary of military personnel, police officers, civil servants with special status and the penitentiary administration system could increase from 1,546 RON in May 2016 to almost 2,450 RON in 2017. 
Employees working in the field of social assistance could benefit from the third highest average wage growth in 2017 if the Ministry of Labor's project is adopted in its proposed form. In particular, the average basic salary in social assistance will increase to 2,141 RON in 2017, a 57.2\% compared to the level of the same indicator in May 2016.

The teaching staff in pre-tertiary education will benefit from an increase in the average basic salary by $35.6 \%$ in 2017 , according to the Ministry of Labor project. Thus, the average basic salary of kindergarten teachers, secondary school teachers, post-secondary and high school teachers will increase to almost 3,600 RON in 2017 from 2,653 RON in May 2016.

The smallest average wage growth in 2017 is foreseen for magistrates and auxiliary staff in the judicial system. The average core salary in 2017 for magistrates will increase by $12.8 \%$ to 6,284 RON, according to the unit wage bill. For university education teachers, the average wage growth planned for 2017 is $17.4 \%$ and for Research employees an increase of $18.3 \%$ was proposed by the Ministry of Labour (ec.europa.eu).

\section{Conclusions}

The interest in a rewarding system and policy implemented in public administration institutions is based on the fact that the system and the policies are able to grab the employees attention and increase their interest, not only pertaining to achievements in individual performances but particularly for their contribution in increasing global productivity these enterprises in the near future.

On the other hand, the main challenge faced by a reward system for civil servants is the need to implement the most rational use of the organization's resources and at the same time to ensure the balance between human aspirations and the competitiveness requirements imposed by the system.

According to specialists, the reward system determines the size and types of values (material and non-material) that employees receive in exchange for their activities in an institution. Normally, any reward system for employees in the public system must be based on a set of principles, i.e. include both a financial component and a non-financial reward component. Within the reward system, one of the most important elements is the salary income system. In Romania, the civil servant's salary system is regulated by law, and is composed of 
the following elements: the basic salary, salary bonuses, bonuses and incentives for financial merit.

In conclusion, both the systems and the wage policies within the public administration institutions should not be neglected by the management of these institutions. In this respect, the heads of public institutions must always be aware that wages are one of the main means of meeting not only the basic physical and biological needs of employees but also their social and personal needs. In connection with the definition of the wage system, this system is a coherent form of measures, generally governed by the law of supply and demand, conceived on the basis of economic and social principles, taken simultaneously and interconnected, by which individual salaries are differentiated into an organization or fields of activity.

\section{References}

[1] Profiroiu, M., et al, (2007). Reforma Administrației Publice în Contextul Integrării Europene, European Institute of Romania - Impact studies III.

[2] Savulescu, C. (2017). Public Organization and Human Resource Management, Course National School of Political and Administrative Studies, Bucharest.

[3] Law no. 330/2010 on the unitary remuneration of the personnel paid from public funds, published in the Official Monitor of Romania, Part I, no. 268 / 26.04.2010.

[4] Ministry of Regional Development and Public Administration, (2013). Analiza Tendinţelor Curente Privind Reforme în Domeniul Funcţiei Publice în Țări Membre ale Uniunii Europene şi ale Organizaţiei pentru Cooperare şi Dezvoltare Economică, National Agency of Civil Servants, Bucharest.

[5] European Semester National Reform Program in Romania (2017). Retrieved from https://ec.europa.eu/info/sites/info/files/2017-european-semester-national-reformprogramme-romania-ro.pdf. 